ТА ІНЖЕНЕРІЯ

УДК 004.652

DOI: https://doi.org/10.11603/mie.1996-1960.2018.2.9295

\title{
МЕТОДОЛОГІЯ ОРГАНІЗАЦІЇ КЛІНІЧНИХ ВИПРОБУВАНЬ ЕФЕКТИВНОСТІ ТА БЕЗПЕЧНОСТІ КИТАЙСЬКОЇ ОБРАЗНОЇ МЕДИЦИНИ В КОНТЕКСТІ ДОКАЗОВОї МЕДИЦИНИ
}

\author{
В. П. Марценюк, С. А. Лупенко, А. С. Сверстюк², А. В. Павлишин ${ }^{2}$ \\ Університет Бєльсько-Бяли, Республіка Польща \\ ${ }^{1}$ Тернопільський національний технічний університет імені І. Пулюя \\ ${ }^{2} Д В Н 3$ «Тернопільський державний медичний університет \\ імені І. Я. Горбачевського МОЗ України»
}

\begin{abstract}
Стаття присвячена обґрунтуванню актуальності розробки методології організації клінічних випробувань ефрективності та безпечності китайської образної медицини в контексті доказової медицини. У роботі розглянуто стратегію організації та проведення клінічних випробовувань китайської образної медицини. Розроблено інформаційну систему забезпечення проведення клінічних випробовувань китайської образної медицини.
\end{abstract}

Ключові слова: методологія клінічних випробувань, китайська образна медицина, доказова медицина, інформаційна система.

\section{METHODOLOGY FOR ORGANIZING CLINICAL TRIALS ON THE EFFECTIVENESS AND SAFETY OF CHINESE FIGURATIVE MEDICINE IN THE CONTEXT OF EVIDENCE-BASED MEDICINE}

\author{
V. P. Martsenyuk, S. A. Lupenko¹, A. S. Sverstiuk², A. V. Pavlyshyn² \\ University of Bielsko-Biala, the Republic of Poland \\ ${ }^{1}$ Ternopil National Technical University n. a. I. Puluj \\ ${ }^{2}$ SHEE «I. Horbachevsky Ternopil State Medical University of the Ministry of Health of Ukraine»
}

The article is devoted to the substantiation of the relevance of the development of a methodology for organizing clinical trials of the effectiveness and safety of Chinese figurative medicine in the context of evidence-based medicine. The paper considers the strategy of organizing and conducting clinical trials of Chinese figurative medicine. An information system for conducting clinical tests of Chinese figurative medicine has been developed.

Key words: methodology of clinical trials, Chinese visual medicine, evidence-based medicine, information system.

\section{МЕТОДОЛОГИЯ ОРГАНИЗАЦИИ КЛИНИЧЕСКИХ ИСПЫТАНИЙ ЭФФЕКТИВНОСТИ И БЕЗОПАСНОСТИ КИТАЙСКОЙ ОБРАЗНОЙ МЕДИЦИНЫ В КОНТЕКСТЕ ДОКАЗАТЕЛЬНОЙ МЕДИЦИНЫ}

\author{
В. П. Марценюк, С. А. Лупенкоㄹ, А. С. Сверстюк², А. В. Павлишин² \\ Университет Бельско-Бялы, Республика Польша \\ ${ }^{1}$ Тернопольский национальный технический университет имени И. Пулюя \\ ${ }^{2} Г$ ГВУЗ «Тернопольський государственный медицинский университет \\ имени И. Я. Горбачевского МЗ Украины»
}

\begin{abstract}
Статья посвящена обоснованию актуальности разработки методологии организации клинических испытаний эффрективности и безопасности китайской образной медицины в контексте доказательной медицины. В работе рассмотрены стратегии организации и проведения клинических испытаний китайской образной медицины. Разработана информационная система обеспечения проведения клинических испытаний китайской образной медицины.
\end{abstract}

\footnotetext{
Ключевые слова: методология клинических испытаний, китайская образная медицина, доказательная медицина, информационная система.
}

() В. П. Марценюк, С. А. Лупенко, А. С. Сверстюк, А. В. Павлишин 
Вступ. Актуальність наукових клінічних досліджень китайської образної медицини (KOM). Розвиток та вдосконалення медицини, інфраструктури надання населенню медичних послуг є важливим та актуальним завданням, яке стоїть перед фахівцями як медичної, так і інших сфер діяльності людини. На сьогодні, в епоху інтенсивної глобалізації економіки, політики, науки, технологій, суспільного та культурного життя, процеси глобалізації та інтеграції не оминули і медичну галузь. Зокрема це стосується і проблеми інтегрування, синтезу, взаємного узгодження та доповнення конвенційної (західної) та неконвенційної (альтернативної, комплементарної) медицини, що проявилося у формуванні такого сучасного напряму медицини, як інтегральна (інтегративна) медицина [3-7].

Здоров’я - одне з головних надбань людини. Між тим, у міру розвитку цивілізації, зростає і число факторів, що ушкоджують здоров’я. Кількість хвороб, відомих сучасній медицині, становить вже понад 10 тисяч одиниць. Західна медицина все більше заходить у «глухий кут», оскільки в основі її принципів лікування закладено використання фармакологічних препаратів — чужорідних для організму хімічних речовин. Кожне їх застосування породжує нові проблеми, оскільки нешкідливих для організму людини препаратів просто не існує. У гострий період хвороби їх застосування, можливо, виправдано, а ось для профілактики і лікування хронічних процесів такий підхід не приносить бажаних результатів, оскільки при цьому страждає якість життя хворих.

Основи КОМ принципово інші. Це цілісна філософія, унікальні методи лікування і профілактики, високоефективні лікувальні засоби, які черпають свою силу в законах самої природи. Висловлювання: «Людина хвора не тоді, коли у неї виникає хвороба, а хвороба виникає тоді, коли людина хвора» абсолютно точно відображає суть погляду китайської медицини на здоров’я людини. Коли захисні сили організму ослаблені, а резерви вичерпані, безліч чинників вступає у взаємодію, допускаючи виникнення хвороби. Джерелом хвороби може з'явитися будь-яка умова, що створює напруження для організму, з якими він не може впоратися. Це може бути і шкідлива речовина, й інше відчуття, і надлишкові кліматичні фактори, такі як тепло, вологість, холод та ін.

Здоров’я в китайській медицині розглядається як здатність організму реагувати на широку різноманітність подразників таким чином, щоб підтримувалися рівновага і цілісність.

Основним правилом лікування є усунення причини захворювання, з урахуванням індивідуальних особливостей, конституції, географічного положення, пори року та ін.

Мета дослідження: представлення сучасної технології збору, аналізу, синтезу та застосування наукової медичної інформації КОМ для прийняття оптимальних клінічних рішень.

Результати та їх обговорення. Доказова медицина. Принципи, методи та ступені вірогідності клінічних випробувань. Доказова медицина (англ. evidence-based medicine - медицина, що базується на доказах; науково обгрунтована медична практика) — підхід до медичної практики, при якому рішення про застосування профілактичних, діагностичних і лікувальних заходів приймаються виходячи 3 наявних доказів їх ефективності та безпеки, а такі докази піддаються пошуку, порівнянню, узагальненню та широкому розповсюдженню для використання в інтересах хворих (Evidence Based Medicine Working Group, 1993). Використовується в щоденній медичній практиці (у діагностиці, лікуванні й профілактиці) медичних технологій i лікарських препаратів, ефективність яких доведена у фармакоепідеміологічних дослідженнях із застосуванням математичних оцінок імовірності успіху й ризику.

Відомо, що навіть існуючі тривалий час медичні традиції і «загальновизнані методи» досі не були піддані адекватній науковій перевірці. Поступово в медицині виникали ідеї, що підвищують її ефективність, наприклад «золотий стандарт терапії» i «препарат вибору».

Доказова медицина поширилася наприкінці 80-х років XX ст. як концепція нового клінічного мислення в процесі формування нової галузі медичних знань — клінічної епідеміології, що використовує методи епідеміології стосовно результатів застосування різних медичних технологій. Доказову медицину можна визначити як новітню технологію збирання, аналізу, синтезу та застосування наукової медичної інформації, яка дозволяє приймати оптимальні клінічні рішення як з погляду допомоги хворому, так і економічної ефективності. У процесі становлення доказової медицини сформувалися такі напрямки медичної науки: фармакоепідеміологія, нові напрямки фармакоінформатики, фармакоекономіка, формулярна система. 
Принципи доказової медицини. В основі доказової медицини лежить перевірка ефективності та безпеки методик діагностики, профілактики та лікування в клінічних дослідженнях. Під практикою доказової медицини розуміють використання даних, отриманих з клінічних досліджень, в повсякденній роботі лікаря.

У більшості країн стали загальновизнаними деякі правила проведення клінічних досліджень, викладені в стандарті GCP (Good Clinical Practice, «Належна клінічна практика»), а також правила виробництва лікарських засобів (стандарт GMP — Good Manufacturing Practice; «Належна виробнича практика») та виконання лабораторних досліджень (стандарт GLP — Good Laboratory Practice; «Належна лабораторна практика»).

Головний принцип доказової медицини - кожне клінічне рішення повинно грунтуватися на наукових фактах, що доведені статистично на великій репрезентативній групі пацієнтів; жодна нова медична технологія (новий метод лікування, діагностики, профілактики) не може бути визнана без обов'язкової перевірки в умовах проведення рандомізованих контрольованих досліджень. Механізмом упровадження принципів доказової медицини в широку клінічну практику є проведення стандартизації медичної допомоги та впровадження формулярної системи.

Розглянемо основні принципи доказової медицини.

- Принцип використання науково-медичної інформації лише найвищого рівня доказовості.

- Принцип постійного знайомства всіх учасників медичної галузі з досягненнями науки i практики.

- Принцип оптимальної діагностичної доцільності.
- Принцип науково обгрунтованого прогнозу захворювання.

- Принцип постійного підвищення безпеки медичних втручань.

- Принцип стандартизації медичних втручань.

- Принцип мінімізації економічних затрат.

- Принцип колективної відповідальності за високу ефективність діагностичних і лікувальних технологій.

- Принцип постійної оптимізації діяльності національних систем охорони здоров'я.

Методи доказової медицини. Основним методом доказової медицини («золотим стандартом») $є$ рандомізовані контрольовані дослідження, коли пацієнти розподіляються на групи випадковим шляхом з використанням засобів рандомізації. У практичному плані доказова медицина ставить перед собою такі завдання:

1) підвищити якість надання медичної допомоги з огляду на ефективність, безпечність та вартість;

2) оптимізувати діяльність національної системи охорони здоров'я.

До основних понять доказової медицини відносяться експеримент, стандартизація та метрологічна повірка приладів, дотримання вимог рандомізації, статистичної обробки, застосування загальноприйнятих стандартів діагностики та лікування, метааналіз, Кокранівське співробітництво.

Інформація, яка надходить із різних джерел способом, який можна відтворити, дозволяє проводити метааналіз - систематизований аналіз зі статистичними узагальненнями (зіставленням доказів), що включає мету аналізу, вибір способів оцінки результатів, систематизований пошук інформації, аналіз інформації за допомогою статистичних методів, інтерпретацію результатів.

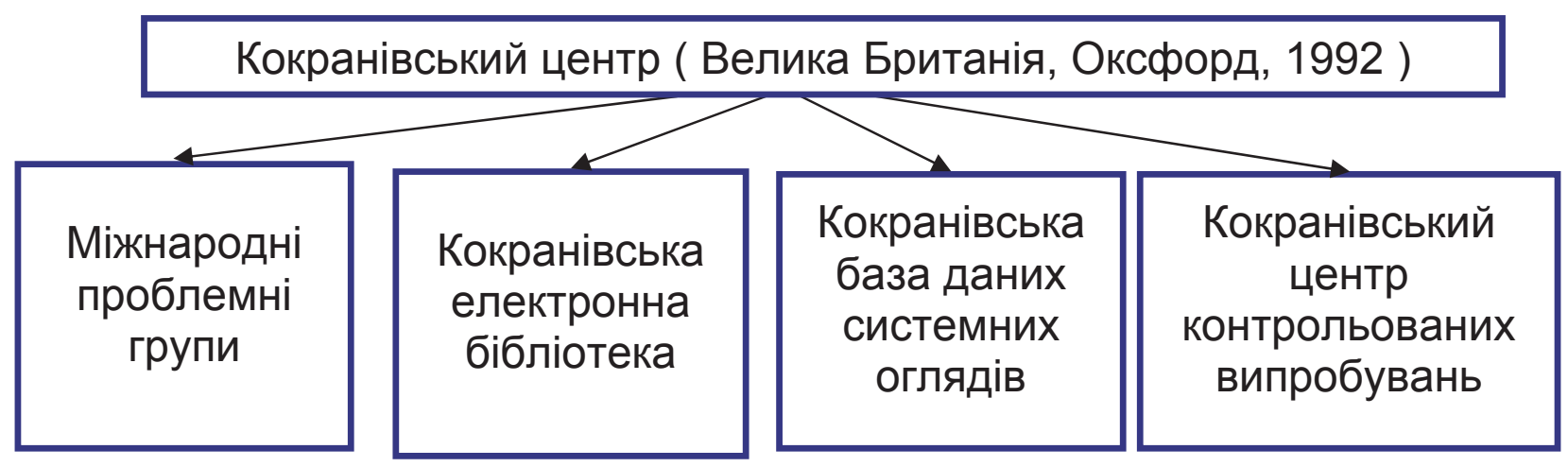

Рис. 1. Структура Кокранівського центру 
Важлива роль у доказовій медицині належить Кокранівському співробітництву (засноване Арчі Кокраном у 1972 році) — міжнародній організації, метою якої $є$ пошук та узагальнення вірогідної інформації про результати медичних втручань. Серед її засновників - провідні країни світу. До складу цієї організації входить Кокранівський центр, структура якого наведена на рис. 1.

У практичному аспекті медицина, що базується на доказах, є інтеграцією індивідуальних клінічних знань та досвіду в галузі лікування та профілактики.

Важливим аспектом доказової медицини є визначення ступеня вірогідності результатів досліджень, що беруться за основу при складанні систематизованих даних.

Відповідно до рішення Шведської ради з методології оцінки в системі охорони здоров'я, вірогідність різних джерел неоднакова та знижується в такій послідовності: рандомізовані контрольовані дослідження, нерандомізовані контрольовані дослідження з одночасним контролем, нерандомізовані контрольовані дослідження з історичним контролем, когортні дослідження, дослідження типу «випадок - контроль», перехресні клінічні дослідження, результати спостережень, описи окремих випадків.

Зважаючи на рівень наукових досліджень в КОМ, пропонуємо почати з методу опису окремих випадків.

Стратегія організації та проведення клінічних випробовувань КОМ. У лікарняних установах для ефективнішого лікування за допомогою доказових методів дослідження необхідно доповнити існуючі методики лікування методами КОМ.

Одним з напрямів доказової медицини $є$ аналіз результатів клінічних досліджень, причому ступінь вірогідності отриманих результатів залежить від організації клінічних випробовувань.

Аналіз результатів досліджень імідж-терапевтами проводиться згідно діагностичних карт (рис. 2).

Доказова медицина у випробовуванні методів КОМ. Необхідно провести контроль та оцінку клінічної ефективності діяльності імідж-терапевтів, результатів лікування пацієнтів за допомогою імідж-терапевтичних методик, які повинні базуватись на основних засадах стандарту GCP.

Одним з головних аспектів проведення оцінки результативності та надійної ефективності іміджтерапевтів є перш за все захист пацієнта відповідно до Хельсинської декларації 2008 року.
ОЦІНКА СТАНУ ЗДОРОВЯ КЛІЕНТА

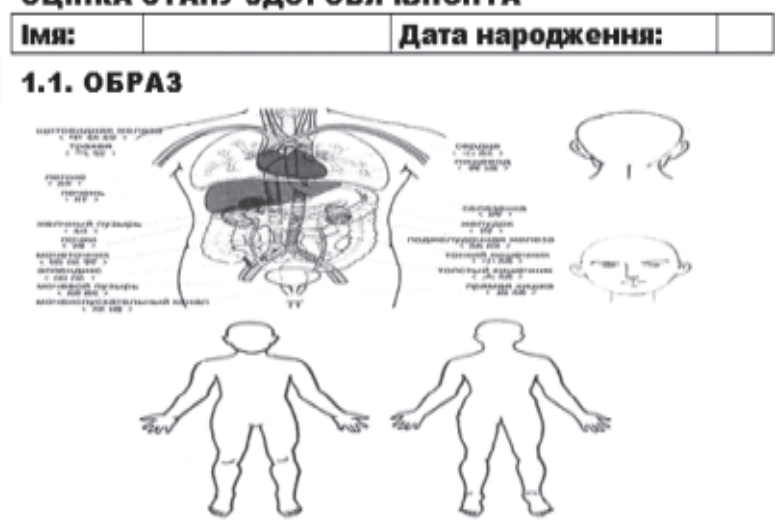

\section{2. СКАРГИ КЛІЕНТА}

\section{3. ДІАГнО3 3 ТОЧКИ ЗОРУ ЗАХІДної МЕДИЦИНИ}

1.4. ПЛАН ДОСЛІДЖЕННЯ. ЛІКАРСЬКІ ЗАСОБИ. ПРИЗНАЧЕННЯ ФАХІВЦЯ

\section{4. ПЛАН ДОСЛІДЖЕННЯ. ЛІКАРСЬК ПРЕПАРАТИ. ПРИЗНАЧЕННЯ ФАХІВЦЯ.}

\begin{tabular}{|l|l|l|}
\hline Дата: & $\begin{array}{l}\text { Пiдпис } \\
\text { спеціаліста: }\end{array}$ \\
\hline
\end{tabular}

Рис. 2. Діагностична карта аналізу результатів досліджень імідж-терапевта

Перед початком клінічних досліджень необхідно протоколи лікування та іншу супровідну документацію погодити в комісії з питань етики лікувально-профілактичної установи, яка також передбачає страхування. Пацієнт при цьому отримує письмову інформацію щодо повного плану запропонованих заходів дослідження, отримує інформовану згоду. Страхуванню піддаються всі пацієнти, які беруть участь в дослідженні. Строк дії страхового договору не може бути меншим, ніж саме дослідження.

Протокол дослідження ефективності іміджтерапевтичних методик КОМ повинен включати зміст, перелік скорочень, загальну інформацію щодо дослідження, мету дослідження, опис самого дослідження, схему дослідження, вибір пацієнтів для дослідження (врахування критеріїв включення в дослідження), лікування, схему терапевтичних впливів, супутнє лікування.

Після підписання інформаційної згоди пацієнти проходять клінічні і лабораторні обстеження, за 
Таблиця 1

Результати обстеження пацієнта

\begin{tabular}{|l|c|c|c|c|}
\hline № візиту & 1 & 2 & 3 & 4 \\
\hline Кількість днів & $2-0$ & 1 & 16 & 30 \\
\hline $\begin{array}{l}\text { Підписання інформованої } \\
\text { згоди }\end{array}$ & $\bullet$ & & & \\
\hline $\begin{array}{l}\text { Демографічні та антропоме- } \\
\text { тричні показники }\end{array}$ & $\bullet$ & & & \\
\hline Медичний анамнез & $\bullet$ & & & \\
\hline $\begin{array}{l}\text { Оцінка критеріїв включення / } \\
\text { невключення }\end{array}$ & $\bullet$ & & & \\
\hline Об’єктивне обстеження & $\bullet$ & & $\bullet$ & $\bullet$ \\
\hline $\begin{array}{l}\text { Систолічний, діастолічний } \\
\text { артеріальний тиск, частота } \\
\text { серцевих скорочень, термо- } \\
\text { метрія }\end{array}$ & $\bullet$ & & $\bullet$ & $\bullet$ \\
\hline Загальний аналіз крові & $\bullet$ & & & $\bullet$ \\
\hline Загальний аналіз сечі & $\bullet$ & & & $\bullet$ \\
\hline Біохімічний аналіз крові & $\bullet$ & & & $\bullet$ \\
\hline Коагулограма & $\bullet$ & & $\bullet$ & $\bullet$ \\
\hline Клінічний огляд, збір скарг & $\bullet$ & & $\bullet$ & $\bullet$ \\
\hline Розподіл пацієнтів по групах & & $\bullet$ & & \\
\hline $\begin{array}{l}\text { Видача досліджуваного пре- } \\
\text { парату }\end{array}$ & $\bullet$ & & \\
\hline Видача щоденника пацієнта & & $\bullet$ & & \\
\hline $\begin{array}{l}\text { Вилучення заповненого що- } \\
\text { денника пацієнта }\end{array}$ & & & & $\bullet$ \\
\hline $\begin{array}{l}\text { Реєстрація побічних реакцій / } \\
\text { побічних явищ }\end{array}$ & $\bullet$ & $\bullet$ & $\bullet$ \\
\hline
\end{tabular}

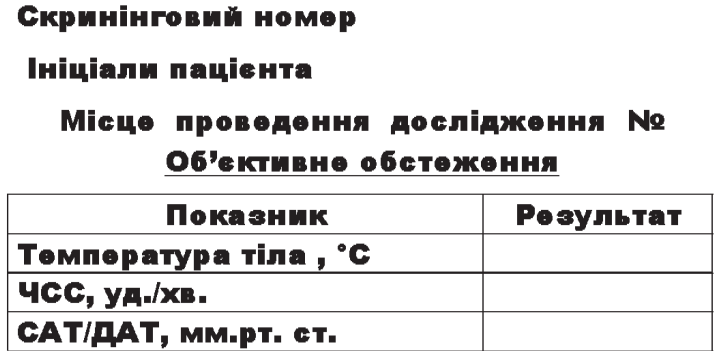

\begin{tabular}{|c|c|c|c|}
\hline \multirow{2}{*}{ No } & \multirow{2}{*}{ Органш та системи } & \multicolumn{2}{|c|}{ Hopma } \\
\hline & & TAK & HI \\
\hline 1 & Загальний стан & & \\
\hline 2 & $\begin{array}{l}\text { Шкірнї покриви, видимі } \\
\text { сливові оболонки } \\
\end{array}$ & & \\
\hline 3 & Серцева-судинна система & & \\
\hline 4 & Oргани дихання & & \\
\hline 5 & Ендокринна сшетема & & \\
\hline 6 & Шлунково-кишкев ий тракт & & \\
\hline 7 & Сечостатева система & & \\
\hline
\end{tabular}
Aara: $\square \square \square \square \square \square \square \square$ minnuc:

Рис. 3. Бланк реєстрації об’єктивного обстеження пацієнта.

Види діагностичної інформації в системі «Імідж-терапевт»

\begin{tabular}{|c|c|}
\hline ація & \\
\hline (вік, & $\begin{array}{c}\text { Медична інформація про пацієнта включає інформацію, яка отримана } \\
\text { методами конвенційної (західної) медицини, а саме історія хвороби } \\
\text { та результати медичних обстежень (лабораторні аналізи, результати } \\
\text { функціональної діагностики, заключення лікаря, тощо) }\end{array}$ \\
\hline $\begin{array}{c}\text { Інформація самооцінки (фізичний } \\
\text { та психологічний стан) пацієнта } \\
\text { до та після терапії, із викорис- } \\
\text { танням методів психологічного } \\
\text { шкалювання }\end{array}$ & $\begin{array}{l}\text { Діагностична інформація, яка отримана методами ТКМ та КОМ, } \\
\text { а саме результати діагностування методами ТКМ (огляд, вислухову- } \\
\text { вання, результати пальпаційного діагностування), результати енерге- } \\
\text { тичного діагностування рукою та внутрішньої образної діагностики }\end{array}$ \\
\hline
\end{tabular}


результатами яких приймається рішення щодо їх включення в клініку.

Аналіз клінічних досліджень пропонуємо проводити згідно табл. 1 та рис. 3.

3 першого дня пацієнти повинні вести щоденники, в яких необхідно реєструвати свої суб’єктивні відчуття після терапії, наявність побічних явищ та ускладнень.

На 16-й та 30-й день досліджень всі учасники проходять повторно лабораторне та інструментальне обстеження.

Інформаційна система забезпечення проведення клінічних випробовувань КОМ. Інформаційна система професійної цілительської діяльності «Імідж-терапевт» призначена для централізованої організації, підвищення якості (ефективності, безпечності, контрольованості, достовірності, економічності, інтенсивності) професійної діяльності та обміну досвідом діючих КОМ-терапевтів [1]. Сформулюємо основні вимоги до цієї інформаційної системи.

1. До складу інформаційної системи повинні входити: 1) електронний персональний кабінет КОМ-фахівця з графічним інтерфейсом; 2) модуль формування результатів діагностування методами КОМ; 3) модуль формування терапевтичних рішень (терапевтичних карт); 4) медична база даних; 5) модуль для обміну даними між КОМ-терапевтами (рис. 4).

2. Інформаційна система «Імідж-терапевт» повинна мати доступ до таких інформаційних систем: база знань КОМ, експертна система КОМ, інформаційна система електронного навчання КОМ, інформаційна система наукових досліджень (ІСНД) КОМ.

3. Модуль формування результатів діагностування методами КОМ повинен забезпечувати ввід персональної та медичної інформації пацієнтів, що включає інформацію, яка отримана методами конвенційної медицини, а саме історія хвороби та результати медичних обстежень (лабораторні аналізи, результати функціональної діагностики, заключення лікаря, тощо), а також включає діагностичну інформацію, яка отримана методами традиційної комплементарної медицини (TKM) та KOM, а саме результати пальпаційного діагностування, результати енергетичного діагностування рукою, результати внутрішньої образної діагностики, та інформацію самооцінки (фізичний та психологічний стан) пацієнта до та після терапії (табл. 2). При цьому пропонуємо використовувати нову генерацію сенсорів (імуносенсори), які використовують в своїй конструкції біологічні матеріали, що надають високу вибірковість, селективність, точність, дають можливість здійснювати швидкі і прості вимірювання біологічних показників. Імуносенсори характеризуються високою ефективністю і широко використовуються в медицині [9] як інструмент для встановлення діагнозів, раннього виявлення речовин, що викликають серцеві захворювання, швидкого виявлення вірусу папіломи людини та ін. На сьогодні імуносенсори є предметом інтенсивних досліджень, що стимулює інтерес і уяву вчених [2, 8].

4. Медична база даних окрім традиційної персональної інформації про пацієнта та його медичних даних, отриманих методами конвенційної медицини (історія захворювань, лабораторні аналізи, результати функціональної діагностики і т. п.), міститиме дані візуальної (образної) діагностичної інформації КОМ-фахівця, а також терапевтичні схеми, які застосовував імідж-терапевт, лікуючи пацієнта. Елементи медичної бази даних повинні використовуватися як конкретні екземпляри класів онтології КОМ, входячи таким чином до складу онтоорієнтованої бази знань КОМ.

Узагальнену архітектуру інформаційної системи професійної цілительської діяльності «Іміджтерапевт» подано на рис. 4.

Зважаючи на нестандартний, незвичний для західної медицини характер діагностичних методів та діагностичної інформації в КОМ, перед створенням інформаційної системи «Імідж-терапевт» необхідно приділити значну увагу розробці нових моделей, методів та засобів подання діагностичної інформації, зокрема образної інформації в КОМ. Насамперед, необхідно розробити інтерактивну інформаційну підсистему відображення образної діагностичної інформації. Основний підхід до розробки інтерактивної системи відображення образної діагностичної інформації КОМ грунтується на образній моделі тіла людини та його ділянок, включаючи фізичний, енергетичний та інформаційний їх аспекти. А саме, ця модель повинна включати у себе ієрархічно організовану множину А вкладених розбиттів образа тіла людини на ділянки (частини тіла людини, системи органів, окремі органи та ділянки органів), множину відношень R між 


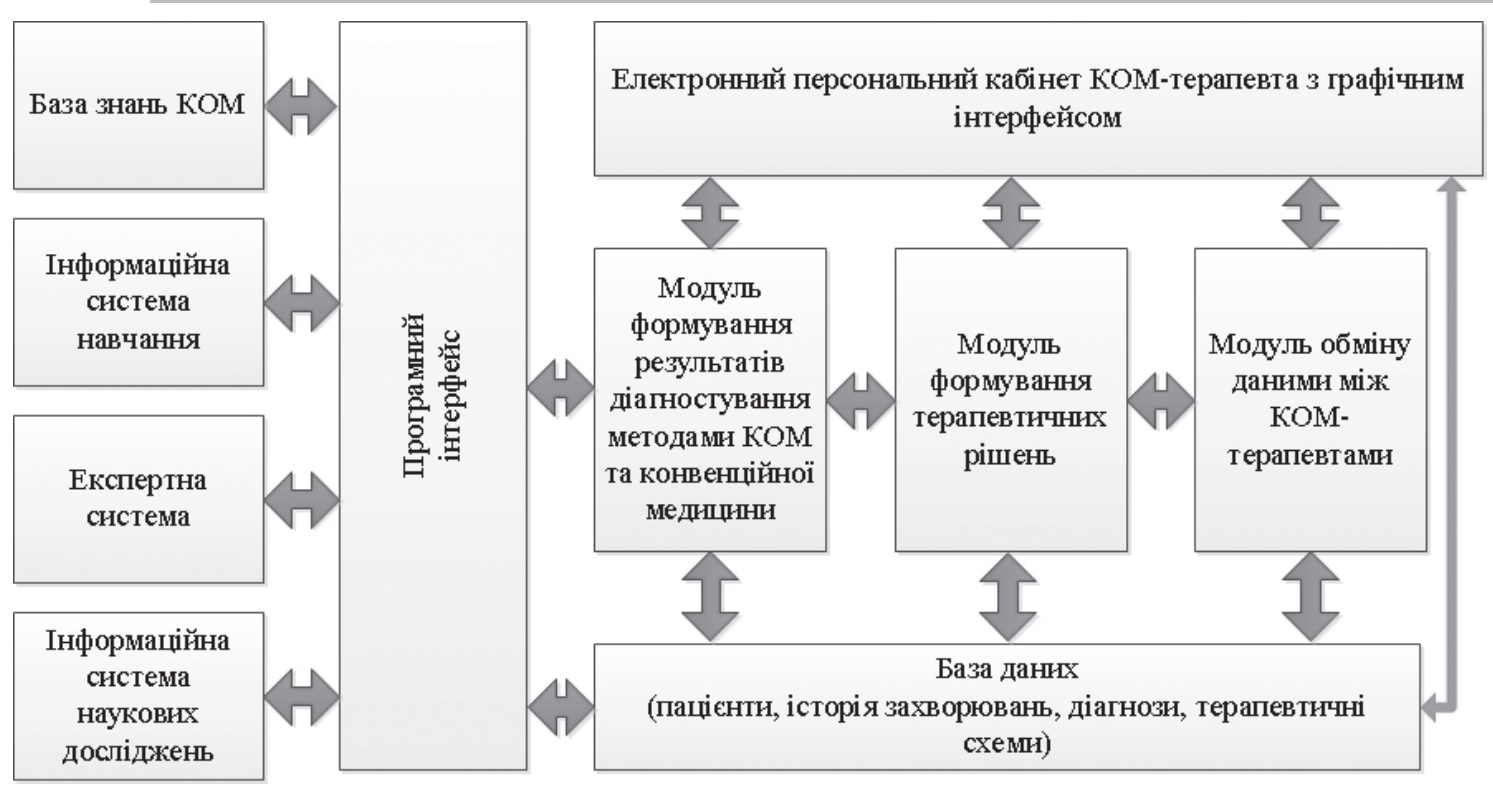

Рис. 4. Узагальнена архітектура інформаційної системи професійної цілительської діяльності «Імідж-терапевт»

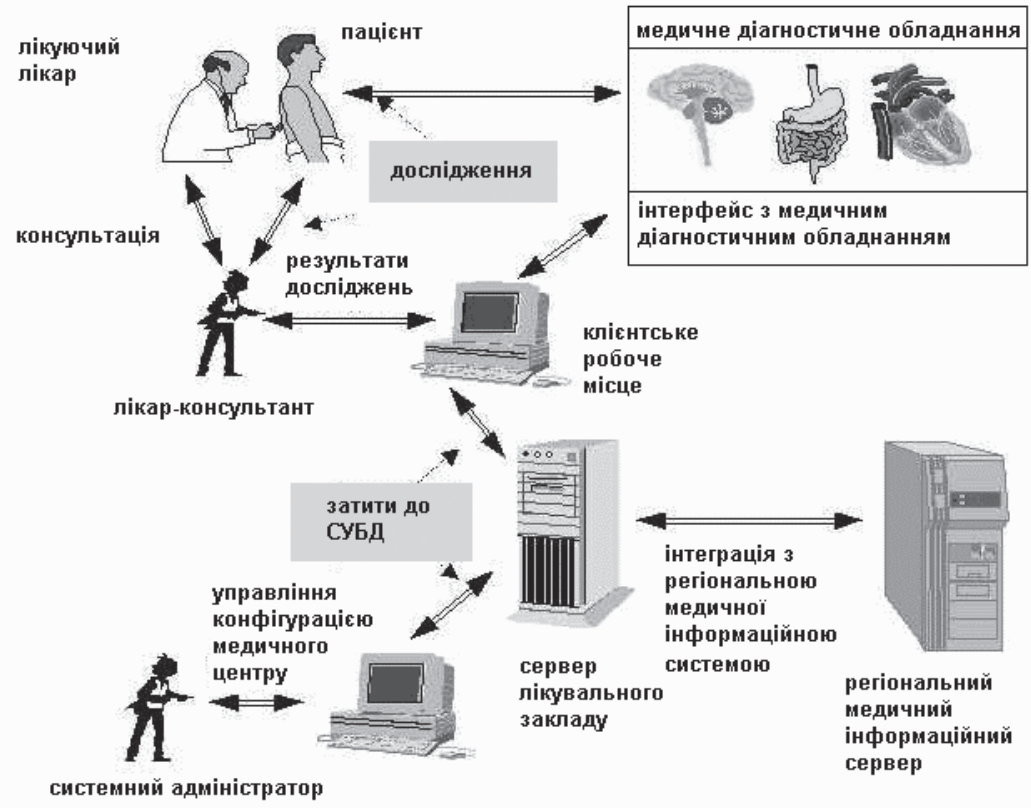

Рис. 5. Узагальнена схема збору діагностичної інформації

елементами цих розбиттів, що відображають патологічні взаємозв'язки, виявлені КОМ-фахівцем, а також множини атрибутів, які характеризують кожний елемент розбиття та кожний елемент відношення (фізичний, енергетичний, інформаційний рівні захворювання, ступінь прояву захворювання у певній вимірювальній шкалі (10-бальна шкала), додаткові дані).

Узагальнена схема збору діагностичної інформації представлена на рис. 5.

ІСНД КОМ. Ця система призначена для аналізу, верифікації, прогнозування, оцінювання ефективності, оптимізації результатів діагностування та лікування КОМ-фахівців. ІСНД КОМ дасть змогу провести всебічний аналіз та прогнозування результатів діагностування та лікування КОМ-фахівців, оцінити рівень їх ефективності та безпечності, що є вкрай необхідним та важливим для включення КОМ в лоно інтегральної медицини. Ця система уможливить верифікацію (апробацію) нових концепцій, теорій, моделей, методів, що пояснюють механізми отримання діагностичної інформації та лікувальних ефектів КОМ на підставі результатів дослідження. 


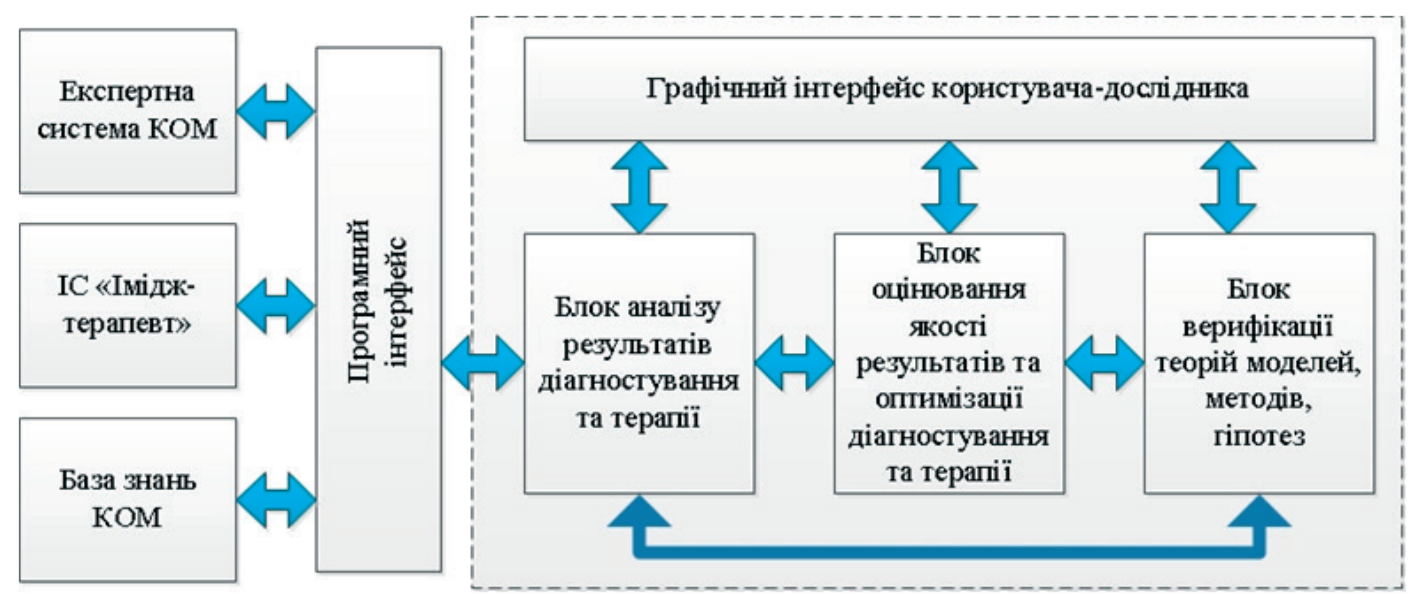

Рис. 6. Узагальнена архітектура ІСНД КОМ

Основними вимогами до ІСНД КОМ є такі:

1. До складу ІСНД КОМ повинні входити: 1) графічний інтерфейс користувача (дослідника, науковця); 2) модуль аналізу результатів діагностування та терапії методами КОМ; 3) модуль оцінювання якості та оптимізації результатів діагностування та терапії методами КОМ; 4) модуль верифікації теорій, моделей, методів та гіпотез у науковому напрямі КОМ.

2. ІСНД КОМ повинна мати доступ до таких інформаційних систем: інформаційна система професійної цілительської діяльності «Іміджтерапевт», база знань КОМ, експертна система KOM.

Узагальнену архітектуру інформаційної системи наукових досліджень подано на рис. 6 .
Для ефективної роботи інформаційної системи професійної цілительської діяльності «Іміджтерапевт» та ІСНД КОМ необхідно забезпечити зв'язок між інформаційними системами діагностичних центрів (рис. 7).

Висновки та перспективи подальших досліджень. Вивчення досвіду КОМ, наукове обгрунтування та впровадження у практику іміджтерапевтичних методів оздоровлення населення, здійснення координаційної та експертної діяльності є важливою проблемою медицини. Доцільність впровадження цих методів у медичну практику підтверджено розробками останніх років.

Подальше вивчення і розвиток методів КОМ повинне приділяти увагу науково-методичному

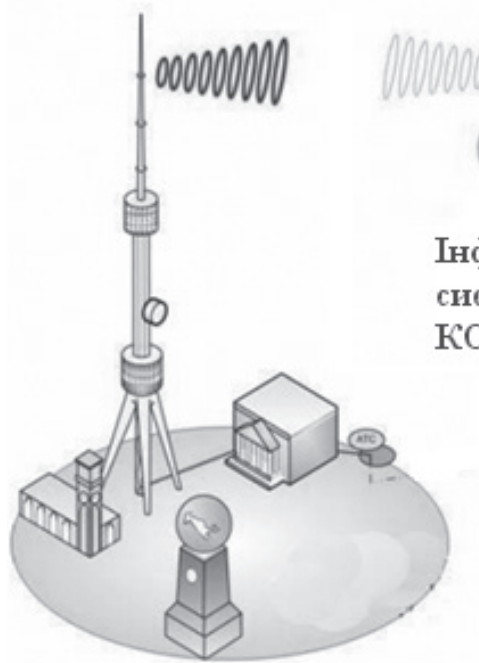

Інформаційна система КОМ

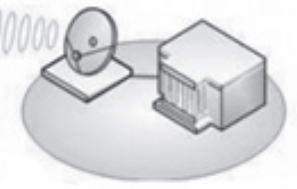

Інформаційна система 1 для КОМ терапевта

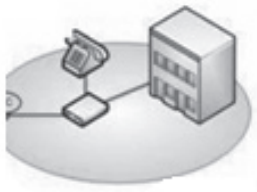

Інформаційна система 2 для KOM терапев та

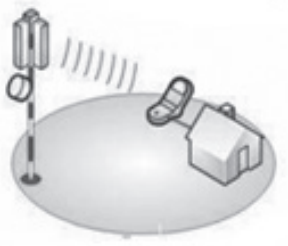

Інформаційна сис тема 3 для КОМ терапев та

Рис. 7. Узагальнена схема зв’язку між інформаційними системами діагностичних центрів 
обгрунтуванню цих методів через впровадження в стандарти лікування, формування цілісного підходу до реформування галузі з метою підвищення рейтингу, покращання якості надання первинної медичної допомоги, реабілітації та профілактики імідж-терапевтичними методами, упередження некомпетентному їх використанню, підвищення рівня довіри до спеціалістів, які використовують ці методи.

1. Проводити подальші заходи щодо висвітлення і впровадження на принципах наукової доказовості методів та засобів КОМ.

2. Консолідувати зусилля лікарів та цілителів на проведенні науково-методичних досліджень 3 використання методів КОМ в медичній практиці.

3. Популяризувати через засоби масової інформації імідж-терапевтичні методи, проводити

\section{Література.}

1. Інтегроване онтоорієнтоване інформаційно-аналітичне середовище наукових досліджень, професійної цілительської діяльності та електронного навчання китайської образної медицини / С. А. Лупенко, Д. В. Вакуленко, А. С. Сверстюк [та ін.] // Інформаційні системи та мережі. — 2017. — № 872. — С. 10-19.

2. Об использовании решетчастых дифференциальных уравнений с запаздыванием для моделирования иммуносенсора / В. П. Марценюк, И. Е. Андрущак, П. Н. Зинько, А. С. Сверстюк // Проблемы управления и информатики. - 2018. - № 3. - С. 37-45.

3. Ananth S. Complementary and alternative medicine survey of hospitals: summary of results / S. Ananth ; Health Forum (American Hospital Association), Samueli Institute. - September 2011. - Режим доступу : http:// www.samueliinstitute.org/File\%20Library/Our\%20 Research/OHE/CAM_Survey_2010_oct6.pdf. — 22 p.

4. Barnes P. M. CDC National health statistics report \#12. The use of complementary and alternative medicine in the United States / P. M. Barnes, B. Bloom, R. Nahin // 2007 National Health Interview Survey (NHIS) / National Center for Complementary and Alternative Medicine (NCCAM), National Center for Health Statistics. — December 2008. — Режим доступу: http:// nccam.nih.gov/news/camstats/2007/cam-survey_fs1. htm (дата звернення : 23.11.2016).

5. Guarneri E. The efficacy and cost effectiveness of integrative medicine: a review of the medical and corporate literature / E. Guarneri, B. Horrigan, C. Pechura // The Journal of Science and Healing. 2010. - Vol. 5. - P. 308-312. роз’яснювальну роботу серед населення щодо використання цих методів з метою збереження та зміцнення здоров’я.

4. Удосконалювати законодавчу базу з урегулювання заняття КОМ шляхом прийняття відповідних постанови Кабінету Міністрів України.

5. Розширювати міжнародне співробітництво та партнерство у галузі КОМ.

6. Впроваджувати методи КОМ в стандарти лікування, реабілітації та профілактики.

7. Сприяти впровадженню в первинну медикосанітарну допомогу лікарських засобів та спеціальних харчових продуктів рослинного, тваринного, мінерального походження, що зареєстровані в установленому порядку в Україні, Європі та інших країнах світу.

6. Horrigan B. What is integrative medicine? / B. Horrigan; The Bravewell Collaborative. - 2010. — Режим доступу: http://www.bravewell.org/integrative_medicine/ what_is_IM. (дата звернення : 23.11.2016).

7. Maizes V. Integrative medicine and patient-centered care / V. Maizes, D. Rakel, C. Niemiec //The Journal of Science and Healing. — 2009. — Vol. 5, No. 5. P. 277-289.

8. Martsenyuk V. P. Stability, bifurcation and transition to chaos in a model of immunosensor based on lattice differential equations with delay / V. P. Martsenyuk, A.rKlos-Witkowska, A. S. Sverstiuk // Electronic Journal of Qualitative Theory of Differential Equations. - 2018. - No. 27. - P. 1-31.

9. Martsenyuk V. P. Study of classification of immunosensors from viewpoint of medical tasks / V. P. Martsenyuk, A. Klos-Witkowska, A. S. Sverstyuk // Medical informatics and engineering. — 2018. — № 1(41). — P. 13-19.

\section{References.}

1. Lupenko, S. A., Vakulenko, D. V., Sverstyuk, A. S., Gorkunenko, A. B., \& Orobchuk, O. R. (2017). Integrovane ontoorientovane informatsiino-analitichne seredovishche naukovikh doslidzhen', profesiinoi tsilitel's'koi diyal'nosti ta elektronnogo navchannya kitais'ko obraznoi meditsini [Integrated ontooriented information and analytical environment for scientific research, professional healing and e-learning of Chinese figurative medicine]. Informatsiini sistemi ta merezhi (Information systems and networks), 872, 10-19. 
2. Martsenyuk, V. P., Andrushchak, I. E., Zin'ko, P. N., \& Sverstyuk, A. S. (2018). Ob ispol'zovanii reshetchastykh differentsial'nykh uravnenii s zapazdyvaniem dlya modelirovaniya immunosensora [On the use of latticed differential equations with delay for simulation of the immunosensor]. Problemy upravleniya i informatiki (Problems of management and informatics), 3, 37-45.

3. Ananth, S. (2011 September). Complementary and alternative medicine survey of hospitals: summary of results. Health Forum (American Hospital Association), Samueli Institute. Retrieved from: http://www. samueliinstitute.org/File\%20Library/Our\%20Research/ OHE/CAM_Survey_2010_oct6.pdf.

4. Barnes, P. M., Bloom, B., \& Nahin, R. (2008 December). CDC National Health Statistics Report \#12. The Use of Complementary and Alternative Medicine in the United States. Findings from the 2007 National Health Interview Survey (NHIS) conducted by the National Center for Complementary and Alternative Medicine (NCCAM) and the National Center for Health Statistics. Retrieved from: http:/nccam.nih.gov/news/ camstats/2007/cam-survey_fs1.htm.
5. Guarneri, E., Horrigan, B., \& Pechura, C. (2010). The efficacy and cost effectiveness of integrative medicine: a review of the medical and corporate literature. The Journal of Science and Healing, 5, 308-312.

6. Horrigan. B. (2010). What is integrative medicine? The Bravewell Collaborative. Retrieved from: http://www. bravewell.org/integrative_medicine/what_is_IM.

7. Maizes, V., Rakel, D., \& Niemiec, C. (2009). Integrative medicine and patient-centered care. The Journal of Science and Healing, 5(5), 277-89.

8. Martsenyuk, V. P., Klos-Witkowska, A., \& Sverstyuk, A. S. (2018). Stability, bifurcation and transition to chaos in a model of immunosensor based on lattice differential equations with delay. Electronic Journal of Qualitative Theory of Differential Equations, 27, 1-31. doi: https://doi.org/10.14232/ejqtde.

9. Martsenyuk, V. P., Klos-Witkowska, A., \& Sverstyuk, A. S. (2018). Study of classification of immunosensors from viewpoint of medical tasks. Medical informatics and engineering, 1(41), 13-19. doi: https://dx.doi. org/10.11603/mie.1996-1960.2018.1.8887. 